\title{
ANALISIS POTENSI LEMPUNG OLAHAN DALAM MEREDUKSI LOGAM BERAT PADA LINDI DI SEKITAR TEMPAT PEMBUANGAN AKHIR (TPA) KOTA PEKANBARU
}

\author{
Elvi Yenti
}

\author{
Fakultas Tarbiyah dan Keguruan Universitas Islam Negeri Sultan Syarif Kasim Riau \\ Email: elviyenti10@gmail.com
}

\begin{abstract}
Natural clay is a porous material that has the ability to adsorb as well have exchangeable ions with ions from the outside. In this study, the clay used comes from the District Tualang - Perawang Siak Riau Province. This study aims to determined the extent effectiveness of potential clay that can be used to reduce heavy metals in the leachate generated by the landfill (TPA). Treated clay by physics and chemistry, refined clay is used to reduce heavy metals $(\mathrm{Pb}, \mathrm{Cd}$ and $\mathrm{Fe}$ ). Analysis of heavy metals used AAS (Atomic Absorption Spectrometry). This study showed a change in acidified clays in terms of adsorption. It was characterized by a change in specific surface area was initially 47.8 $\mathrm{m}^{2} / \mathrm{g}$ after activation increased to approximately $64.8 \mathrm{~m}^{2} / \mathrm{g}$, which will greatly affect the magnitude of the absorption capacity of the adsorbent. The effectiveness of adsorption of the heavy metals analyzed stood at 66 to $78.8 \%$ a high rate.
\end{abstract}

Keywords: clay, leachate, heavy metals, landfills (TPA).

\section{PENDAHULUAN}

Tempat Pembuangan Akhir (TPA) merupakan tempat di mana seluruh sampah hasil aktifitas kebersihan penduduk kota berakhir, mulai dari skala rumah tangga, kantor hingga industri diangkut untuk kemudian dibuang di TPA di kota Pekanbaru yang merupakan jenis TPA yang menggunakan sistem open-dumping. Pada sistem open-dumping, sampah ditimbun di areal tertentu tanpa membutuhkan tanah penutup ataupun pengelolaan lainnya. Akibatnya terjadinya pencemaran lingkungan udara, air dan tanah di areal tersebut dan areal sekitarnya.

Pencemaran lingkungan perairan juga dapat terjadi akibat masuknya air eksternal ke dalam tumpukan sampah yang kemudian membawa dan atau melarutkan unsur-unsur dan senyawa berbahaya (Indah, Zulkifli dan Faizal, 2006). Timbulnya limbah cair sebagai akibat masuknya air eksternal ke dalam timbunan sampah kemudian yang kemudian membilas dan melarutkan materi yang ada dalam timbunan tersebut, dikenal dengan istilah lindi atau leachate.

Lindi dapat menimbulkan pencemaran apabila tidak diolah terlebih dahulu sebelum di buang ke lingkungan. Lindi ini pada umunya bersifat toksik karena mengandung mikroorganisme dalam jumlah tinggi, mengandung logam berat yang berbahaya jika terpapar ke lingkungan, dan lain-lain. Selain itu tingkat kemampuan degradasi air lindi di alam rendah, hal ini ditandai dengan rendahnya nilai rasio BOD/COD (Trihadiningrum, 1995)

Untuk itu diperlukan solusi yang cermat untuk mengatasi persoalan ini. Solusi yang dibutuhkan adalah mengolah limbah dengan sains dan teknologi tepat guna, sederhana dan murah dengan memanfaatkan sumber daya alam yang melimpah dan murah. Salah satu adalah dengan melakukan pengolahan secara kimia menggunakan bahan penyerap seperti magnesium hidroksida, natrium hidoksida, tawas, kapur, lempung dan lain-lain (Sunardi, Suparno dan Yuwono, 2011). Diantara bahan kimia tersebut, lempung adalah bahan yang termurah dan mudah diperoleh serta merupakan sumber daya alam yang dapat ditemukan dipermukaan tanah. Selain itu lempung alam juga merupakan sumber daya alam yang banyak terdapat di provinsi Riau, namun pemanfaatannya masih belum optimal.

Kemampuan lempung sebagai adsorben karena di dalam mineral lempung mengandung senyawa alumunium silikat yang memiliki struktur kerangka tiga dimensi terbentuk oleh tetrahedral $\mathrm{AlO}_{4}{ }^{5-}$ dan $\mathrm{SiO}_{4}{ }^{4-}$ dengan rongga di dalamnya terisi ion-ion logam biasanya logam 
alkali tanah (Na, K, Mg, Ca dan Fe) dan molekul air yang dapat bergerak bebas. Sifat-sifat ini yang menjadikan mineral lokal lempung dapat dimanfaatkan sebagai bahan penyerap logam berbahaya dalam limbah cair, penyaring molekul dan sebagai penukar ion (Sunardi, Suparno dan Yuwono, 2011).

Namun demikian, lempung yang dapat digunakan sebagai adsorben yang efisien, haruslah diolah terlebih dahulu melalui proses pengaktifan fisika maupun pengaktifan kimia. Sifat adsorben akan lebih efektif karena diharapkan akan adanya pembentukan kerangka struktur molekuler dari penggabungan molekulmolekul tetrahedral membentuk celah dan saluran yang teratur sehingga menyebabkan adanya struktur berpori. Celah dan saluran dalam struktur yang terjadi memungkinkan suatu molekul yang mungkin melewatinya dapat terperangkap di dalamnya (Sunardi, Suparno dan Yuwono, 2011). Untuk itu, dibutuhkan penelitian guna mengetahui sejauhmana potensi lempung olahan ini dapat digunakan secara ekfektif untuk mereduksi logam berat dalam lindi.

\section{METODOLOGI PENELITIAN}

\section{Alat}

Alat-alat yang digunakan dalam penelitian ini adalah:AAS (Atomic Absorption Spectrophotometry), Oven, Tanur, Autoklav dan Kolom, botol sampel yang bersih,

peratan gelas, cawan, oven, desikator, kertas saring Whatman No.1, AAS (Spektrofotometer Serapan Atom) Flame AA-6300 Shimadzu, Spektofotometer DR 2800, turbidimeter, autoklap, timbangan analitik, pipet ukur, tabung Durham, petridish, penangas air, magnetik stirer, alat penyaring, pompa vakum, pembakar bunsen, $\mathrm{pH}$ meter, termometer dan Chemical Glassware penunjang lainnya.

\section{Bahan}

Bahan-bahan yang digunakan dalam penelitian ini terdiri dari bahan yang merupakan sampel penelitian dan reagen kimia penunjang. Sampel penelitian adalah lindi yang diambil dari Tempat Pembuangan Akhir di kota Pekanbaru, dan lempung olahan. Sementara bahan/reagen kimia penunjang yaitu, Asam Nitrat, Media Agar dan Laktosa Cair.

\section{Prosedur Kerja}

\section{Persiapan Sampel Penelitian}

Sampel Penelitian yang berupa lindi diambil dari kolam penampungan lindi di Tempat pembuangan Akhir di Muara Fajar, Kota Pekanbaru, menggunakan botol kaca bersih yang sudah disterilkan dalam oven. Sampel ini dibawa ke laboratorium untuk dianalisis.

\section{Pengolahan Lempung}

Lempung alam diambil secara acak di lokasi, dicuci, dan dikering-anginkan selama beberapa hari. Lempung ini dihaluskan dengan grinder dan diayak dengan ukuran partikel 300$500 \mu \mathrm{m}$. Serbuk lempung direndam di dalam air suling selama 5 jam sambil sesekali diaduk dan didiamkan satu malam. Cairan bagian atasnya dipisahkan dan suspensi bagian bawah disaring dan dikeringkan pada suhu kamar selama beberapa hari. Lempung dibersihkan dan dihaluskan, kemudian direndam dangan asam sulfat $10 \%$ selama 10 jam. Selanjutnya dicuci dengan akuades sampai bebas asam dan dikeringkan.

\section{Adsorbsi Logam Berat oleh Lempung}

Proses penyerapan dilakukan dengan 2 cara yaitu dengan proses stirring dan tanpa proses stirring. 0,5 gram lempung yang telah dikalsinasi pada suhu $500^{\circ} \mathrm{C}$ dimasukkan kedalam $250 \mathrm{ml}$ larutan lindi dan diaduk dengan magnetic-stirrer selama 1 jam. Setelah itu dilakukan penyaringan. Filtrat ditampung dan dianalisa dengan AAS.

Untuk proses tanpa stirring dilakukan dengan cara yang sama, tanpa pengadukan, dan dengan menggunakan kolom.

\section{Analisis Logam Berat pada Sampel Air}

Logam berat yang dianalisis adalah $\mathrm{Pb}, \mathrm{Cd}$ dan $\mathrm{Fe}$ untuk sampel air lindi berdasar pada APHA/AWWA/WEF Standard Methods, 20th Edition, 2001, dimana ekstraksi logam berat dilakukan dengan metode pemekatan sampel 
dengan asam nitrat pekat $\left(\mathrm{HNO}_{3}\right)$. Lima belas $\mathrm{ml}$ $\mathrm{HNO}_{3}$ ditambahkan ke $250 \mathrm{ml}$ sampel air kemudian dipanaskan hingga $25 \mathrm{ml}$. Lalu, larutan dipindahkan $50 \mathrm{ml}$ labu ukur kemudian diencerkan dengan aquadest hingga mencapai tanda $50 \mathrm{ml}$. Besarnya konsentrasi logam berat dianalisis dengan menggunakan Atomic Absorption Spectrometer (AAS), tipe flame. Prosedur ini dilakukan dengan sistem duplo.

\section{HASIL DAN PEMBAHASAN}

Penelitian terhadap kandungan logam Timbal, Cadmium dan Besi yang terdapat dalam cairan sampel lindi yang diambil dari kolam penampungan lindi di TPA di Muara Fajar kota Pekanbaru, memberikan hasil sebagaimana terlihat pada Tabel. 1 .

Tabel 1. Konsentrasi Logam Timbal, Cadmium dan Besi dalam Lindi

\begin{tabular}{lc}
\hline Jenis Logam & Konsentrasi $(\mathrm{mg} / \mathrm{L})$ \\
\hline Timbal $(\mathrm{Pb})$ & $0,054-0,228$ \\
\hline Cadmium $(\mathrm{Cd})$ & $0,003-0,045$ \\
\hline Besi $(\mathrm{Fe})$ & $4,06-4,86$ \\
\hline
\end{tabular}

Lindi yang dianalisis adalah Lindi dari kolam ke 4, setelah melewati proses biofolter dalam tiap kolam Lindi seperti terlihat pada Gambar 1. Lindi dalam kolam ke 4 langsung dibuang ke dalam saluran yang berakhir di sungai di belakang TPA.

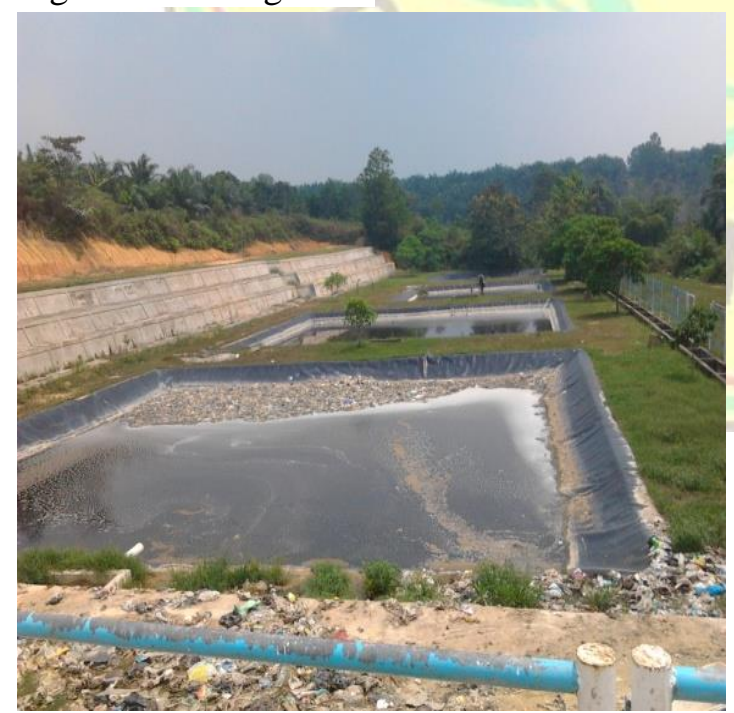

Gambar 1. Kolam Penampungan Lindi di TPA Muara Fajar Pekanbaru

Lempung sebagai adsorben di ambil dari daerah

Tualang-Perawang
Kabupaten Siak Provinsi Riau. Lempung ini bertekstur halus dan berwarna coklat- keabuabuan seperti terlihat pada gambar 2 .

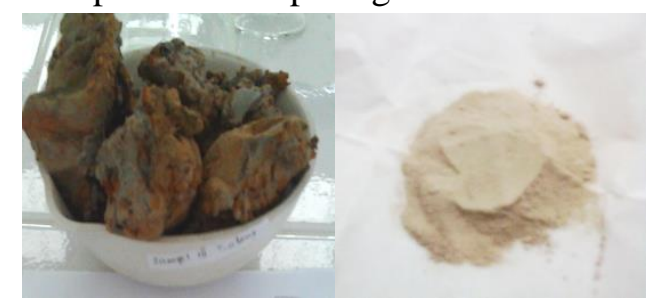

(a)

(b)

Gambar 2. Lempung Tualang-Perawang (a) sebelum diolah (b) setelah diolah

Lempung dikeringkan, diayak, diasamkan dan di kalsinasi pada suhu $500^{\circ} \mathrm{C}$ selama 8 jam, untuk kemudian siap digunakan sebagai adsorben.

Lempung setelah aktivasi pengasaman memiliki luas permukaan spesifik yang lebih tinggi dibanding sebelumnya. Lempung sebelum aktivasi hanya memiliki luas permukaan spesifik sekitar $47,8 \mathrm{~m}^{2} / \mathrm{g}$ sedangkan setelah aktivasi meningkat menjadi sekitar $64,8 \mathrm{~m}^{2} / \mathrm{g}$.

Proses adsorbsi logam berat dan microba patogen oleh lempung yang telah diolah dilakukan dengan cara stirring dan non-stirring selama satu jam untuk melihat efektifitas perbedaan perlakuan. Konsentrasi logam berat dalam Lindi yang diadsorbsi oleh lempung dengan pH 5 menunjukkan efektifitas adsorbsi seperti pada Tabel 2.

Tabel 2. Efektifitas Adsorbsi logam $\mathrm{Pb}, \mathrm{Cd}$ dan $\mathrm{Fe}$ dalam lindi

\begin{tabular}{lccc}
\hline \multirow{2}{*}{ Perlakuan } & \multicolumn{3}{c}{ Efektifitas Adsorbsi } \\
\cline { 2 - 4 } & $\mathrm{Pb}$ & $\mathrm{Cd}$ & $\mathrm{Fe}$ \\
\hline Stirring & $78,8 \%$ & $67,6 \%$ & $72,2 \%$ \\
\hline Non Stirring & $74,2 \%$ & $66,5 \%$ & $71,4 \%$ \\
\hline
\end{tabular}

Hasil diatas menunjukkan bahwa proses stirring tidak menunjukkan perbedaan yang signifikan dalam hal efektifitas adsorbsi logam oleh lempung.

Pengolahan lempung alam di Pekanbaru memiliki potensi positif untuk terus dikembangkan. Dalam penelitian ini, lempung asal Kecamatan Tualang-Perawang Kabupaten Siak Provinsi Riau menunjukkan potensinya dalam pengolahan limbah. Pengolahan lempung diawali dengan mengering-anginkannya selama 
beberapa hari guna menghilangkan zat-zat volatil yang terkandung didalamnya, tanpa merusak struktur dasar lempung. Kemudian lempung dihaluskan dengan grinder dan diayak dengan ukuran partikel 300-500 $\mu \mathrm{m}$, guna mengurangi konsentrasi pasir atau komponen lain yang tercampur dalam lempung secara fisika. Perendaman serbuk halus lempung di dalam air suling dimaksudkan untuk melarutkan zat non-lempung dan disaring agar terpisah. Lempung yang telah dibersihkan secara fisika, selalu dikeringkan pada suhu kamar untuk menjaga struktur lempung. Pengasaman dengan asam sulfat dilakukan guna meningkatkan kemampuan adsorbsi lempung. Kalsinasi gelpori dengan membebaskan pengotor lain. Proses penyerapan dilakukan dengan stirring dan tanpa proses stirring dilakukan untuk mengetahui sejauhmana efektifitas kontak lempung melalui pengadukan mempengaruhi penyerapan. Namun hasil penelitian menunjukkan bahwa kedua proses tidak menunjukkan perbedaan hasil reduksi yang signifikan. Padahal proses stirring dalam implementasinya untuk pengelolaan lindi membutuhkan peralatan dan biaya lebih dibanding tanpa stirring. Karenanya hasil penelitian ini tidak merekomendasikan proses stirring mengingat kesulitan pengelolaannya di lapangan. Namun demikian, hal ini tidak menutup kemungkinan dilakukannya penelitian lanjutan untuk proses kontak lindi dengan lempung melebihi waktu 1 jam.

Hasil penelitian ini juga menunjukkan bahwa terjadi perubahan pada lempung yang diasamkan dalam hal adsorbsi. Hal ini ditandai dengan terjadinya perubahan luasnya permukaan spesifik yang awalnya $47,8 \mathrm{~m}^{2} / \mathrm{g}$ sedangkan setelah aktivasi meningkat menjadi sekitar $64,8 \mathrm{~m}^{2} / \mathrm{g}$, dimana ini akan sangat mempengaruhi besarnya kapasitas penyerapan dari adsorben. Luas permukaan spesifik merupakan parameter yang menggambarkan kapasitas adsorpsi suatu adsorben.

Hasil analisis Logam $\mathrm{Pb}, \mathrm{Cd}$ dan $\mathrm{Fe}$ menunjukkan bawa konsentrasi logam berat dalam lindi yang langsung dibuang ke perairan akan dapat membahayakan. Konsentrasi logam yang diperbolehkan sesuai baku mutu air kelas
IV berdasarkan Peraturan Pemerintah Nomor 82 Tahun 2001 untuk $\mathrm{Pb}$ adalah $1 \mathrm{mg} / \mathrm{L}, \mathrm{Cd} 0,01$ $\mathrm{mg} / \mathrm{L}$ dan Fe 0,00 mg/L.

Secara kuantitas, konsentrasi logam $\mathrm{Fe}$ dan $\mathrm{Pb}$ dalam lindi kolam 4 TPA Muara Fajar tidak melebihi baku mutu air kelas IV. Hanya logam Cadmium yang melebihi standar baku mutu. Namun demikian, konsentrasi $\mathrm{Pb}$ jauh melebihi baku mutu air kelas III yaitu $0,3 \mathrm{mg} / \mathrm{L}$, sedangkan konsentrasi Fe melebihi baku mutu air kelas I yaitu $0,3 \mathrm{mg} / \mathrm{L}$.

Bila dilihat standar baku mutu klasifikasi mutu air sebagaimana yang ditetapkan pemerintah (PP Nomor 82 Tahun 2001 Pasal 8) menjadi 4 (empat) kelas yaitu:

- Kelas satu, air yang peruntukannya dapat digunakan untuk air baku air minum, dan atau peruntukan lain yang mempersyaratkan mutu air yang sama dengan kegunaan tersebut;

- Kelas dua, air yang peruntukannya dapat digunakan untuk prasarana/sarana rekreasi air, pembudidayaan ikan air tawar, peternakan, air untuk mengairi pertanaman, dan atau peruntukan lain yang mempersyaratkan mutu air yang sama dengan kegunaan tersebut;

- Kelas tiga, air yang peruntukannya dapat digunakan untuk pembudidayaan ikan air tawar, peternakan, air untuk mengairi pertanaman, dan atau peruntukan lain yang mempersyaratkan mutu air yang sama dengan kegunaan tersebut;

- Kelas empat, air yang peruntukannya dapat digunakan untuk mengairi pertanaman dan atau peruntukan lain yang mempersyaratkan mutu air yang sama dengan kegunaan tersebut maka air tersebut tidak dapat digunakan secara leluasa karena dapat membahayakan semisal digunakan untuk peternakan, untuk pembudidayaan, apalagi untuk keperluan rumah tangga.

Ketiga jenis logam ini dipilih untuk dianalisis mengingat untuk daerah perkotaan, logam-logam ini biasanya memiliki konsentrasi yang relatif cukup tinggi. Padahal, keberadaan logam ini sangat membahayakan kesehatan manusia. Logam yang berbahaya ini tentu saja 
harus diwaspadai dan dilakukan upaya penanggulangannya. Logam dengan konsentrasi mendekati ambang bahaya ini akan terus menerus kontak dengan lingkungan dan lama kelamaan akan menumpuk, sehingga yang awalnya tidak berdampak, pada akhirnya dapat sangat membahayakan.

Efektifitas adsorbsi terhadap logam berat yang dianalisa juga berada pada angka 66-78,8\% juga merupakan angka yang cukup tinggi. Meskipun konsentrasi $\mathrm{Pb}$ dan $\mathrm{Fe}$ tidak melewati ambang baku mutu IV, namun bagaimanapun reduksi logam berat tetap sangat diperlukan untuk meminimalisasi paparan limbah terhadap lingkungan mengingat bahaya yang dapat ditimbulkannya.

Penelitian tentang pengelolaan lempung asli provinsi Riau dengan cara yang relatif lebih mudah namun memberikan kontribusi yang cukup baik ini diharapkan dapat menjadi sumbangan bagi upaya pengelolaan limbah dimasa yang akan datang. Meskipun demikian, penelitian ini masih perlu disempurnakan terkait dengan opltimalisasi konsentrasi dan waktu pengasaman, serta waktu dan jumlah kontak lindi dengan lempung yang telah diolah.

\section{KESIMPULAN}

Penelitian ini menunjukkan bahwa terjadi perubahan pada lempung yang diasamkan dalam hal adsorbsi. Hal ini ditandai dengan terjadinya perubahan luas permukaan spesifik yang awalnya $47,8 \mathrm{~m}^{2} / \mathrm{g}$ setelah aktivasi meningkat menjadi sekitar $64,8 \mathrm{~m}^{2} / \mathrm{g}$, dimana ini akan sangat mempengaruhi besarnya kapasitas penyerapan dari adsorben.

Efektifitas adsorbsi terhadap logam berat yang dianalisa berada pada angka $66-78,8 \%$

\section{DAFTAR PUSTAKA}

Anirudhan, T.S. dan Radhakrishnan, P.G. 2008. Thermodynamics And Kinetics of Adsorption Of $\mathrm{Cu}(\mathrm{II})$ From Aqueous Solutions Onto A New Cation Exchanger Derived From Tamarind Fruit Shell, J. Chem. Thermodynamics, 40, Pp.702-709.

Bahri, S., Muhdarina dan Fitrah, A. 2010. Lempung Alam Termodifikasi Sebagai
Adsorben Larutan Organik:

Kesetimbangan Adsorbsi Lempung

Terhadap Ion $\mathrm{Cu}^{+2}$. Jurnal Sains Dan

Teknologi, Vol 9(1), Hal 9-13

Bowles, J. E. 1991. Mekanika Tanah (Sifat Sifat Fisis Dan Geoteknis Tanah), Edisi 2.

Darmono. 2001. Lingkungan Hidup dan Pencemaran: Hubungannya dengan Toksikologi Senyawa Logam. Universitas Indonesia Press, Jakarta.

Das, B. M. 1988. Mekanika Tanah (Prinsip Prinsip Rekayasa Geoteknis), Jilid Pertama. Jakarta: Erlangga.

Effendi, H. 2003. Telaah Kualitas Air Bagi Pengelolaan Sumber Daya Dan Lingkungan Perairan. Cetakan Kelima. Yogjakarta: Kanisius.

El-Fadel M. 1999. Leachate Recirculation Effects On Settlement And Biodegradation Rates In MSW Landfills. Environmental Technology 20:121-133

Fadel, E. M., A. N. Findikakis, dan O. J. Leckie. 1997. Environmental Impacts Of Solid

Waste Landfilling. Journal Environments Mgmt. 50:1-25

Garnasih, I. 2009. Tesis. Program Studi Biologi. Institut Teknologi Bandung.Bandung

Grim, Ralph E. 1962. Applied Clay-minerologi. New York: Mc Graw Hillbook Company Inc.

Grim RE. 1968. Clay Mineralogy. New York: Mcgraw-Hill Book Company

Indah, Zulkifli, H., Dan Faizal. 2006. Pengaruh Lindi Tempat Pembuangan Akhir Sampah Baru Putih Kabupaten Oku Terhadap Kualitas Air Di Sekitar TPA. Jurnal Pengelolaan Lingkungan Dan SDA, Volume 4 (2) Hal 37-46.

Ricki M. Mulia, 2005. Kesehatan Lingkungan, Penerbit Graha Ilmu

Nelson, S. A. 200.. "Clay Minerals". Tulane University.

Nurahmi, E. 2001. Uji Stabilitas Struktur Bentonit Terhadap Perlakuan Asam Sulfat Dan Pemanasan. Skripsi. Yogyakarta: FMIPA UGM, Hal. 1 - 2.

Nemerow, L. Nelson Dan A. Dasgupta. 1991. Industrial And Hazardous 
Wastetreatment. Van Nostrand-Reinhold, New York.

Pohland, Frederick G. dan Stephen R. Harper. 1985. Critical Review And Summary Of Leachate And Gas Production From Landfills. U.S. Environmental Protection Agency, Ohio

Santika, S. S. 1984. Metode Penelitian Air. Usaha Nasional. Surabaya.

Suarya, P. 2008. Adsorpsi Pengotor Minyak Daun Cengkeh Oleh Lempung Teraktivasi Asam. Jurnal Kimia 2 (1), Hal 19-24

Sudarwin, 2008. Analisis Spasial Pencemaran Logam Berat (Pb Dan Cd) Pada Sedimen Aliran Sungai Dari Tempat Pembuangan Akhir (TPA) Sampah Jatibarang Semarang. Tesis Program Pasca Sarjana Universitas Diponegoro,Semarang

Sugiharto. 1987. Dasar-Dasar Pengelolaan Air Limbah. Universitas Indonesia. Jakarta
Sunardi, Suparno Dan Yuwono, W. 2011. Adsorpsi Limbah Uranium Menggunakan Lempung Nanggulan. Prosiding Seminar Penelitian Dan Pengelolaan Perangkat Nuklir Pusat Teknologi Akselerator Dan Proses Bahan Yogyakarta,. ISSN 1410 8178 Buku II Hal 111

Trihadiningrum, Y. (1995). Mikrobiologi Lingkungan. Buku Ajar Jurusan Teknik Lingkungan FTSP-ITS: Surabaya

Vogel. 1994. Buku Ajar Vogel Kimia Analisa Kuantitatif Anorganik. Edisi Keempat. Jakarta: Penerbit Buku Kedokteran, EGC. .2001. Peraturan Pemerintah Republik Indonesia Nomor 82 Tahun 2001 Tentang Pengelolaan Kualitas Air Dan Pengendalian Pencemaran Air Presiden Republik Indonesia. 